\title{
Entrevista com deputado federal José Genoíno
}

Christiane Jalles de Paula e Jorge Chaloub

\section{José Genoíno}

A entrevista foi realizada no dia 27 de outubro de 2020, em formato virtual, na plataforma Google Meet. A entrevista foi conduzida pela professora Christiane Jalles de Paula e pelo professor Jorge Chaloub, ambos do Departamento de Ciências Sociais, da Universidade Federal de Juiz de Fora. A entrevista foi transcrita por Gustavo Pereira e revisada pelos entrevistadores.

No dia 27 de outubro de 2020, entrevistamos o deputado federal José Genoíno. A pandemia de Covid 19 impediu nossa ida a São Paulo e nos obrigou a realizar a entrevista por meio de um aplicativo, no caso o Google Meet. O deputado foi solícito e gentil desde o primeiro contato.

A escolha do deputado Genoíno decorreu não apenas por sua atuação na Constituinte, mas também pelos momentos anteriores e posteriores ao evento. Militante pregresso do movimento estudantil católico e da luta armada, ele representa uma trajetória das esquerdas brasileiras durante a Ditadura Militar. A chegada de um ator com tal experiência ao plenário da Assembleia Nacional Constituinte expõe algo sobre um determinado setor das esquerdas então atuantes e, mais especificamente, sobre o Partido dos Trabalhadores (PT), pelo qual ele foi eleito, mas também aponta para as mudanças em curso no país e para o processo de transformação, mesmo que muitas vezes controlada, que marcou toda a Constituinte. Após 1988, Genoíno se destaca como uma das mais relevantes lideranças do PT, seja na oposição ou no governo, partícipe de um processo político atravessado pelas disputas em torno da Constituição, que sempre ocupou um papel central nas lutas políticas das últimas décadas.

O objetivo da entrevista era oferecer ao leitor do dossiê um outro tipo de discurso sobre a Constituinte, que trouxesse a memória de um partícipe e protagonista desse processo. Se nossa proposta é sugerir novos olhares e perspectivas sobre a Constituição, a história oral pode ser um caminho particularmente rico, não apenas por expor aspectos menos analisados do passado, mas, sobretudo, por explicitar os processos de construção da memória em torno do evento. Mais do que um caminho para acessar um passado distante, a memória desponta como meio para compreender seu constante processo de atualizações e reelaborações. Como o próprio entrevistado afirma, há um vínculo entre a memória e a militância, parte de uma dimensão subversiva da própria memória que sempre se estabelece a partir de um liame entre o passado, o presente e o futuro.

\section{Entrevistadores (Christiane Jalles de Paula e Jorge Chaloub):}

Você poderia começar nos contando sobre as suas origens. 


\section{José Genoíno:}

Sou José Genoíno, filho de cearense. Eu nasci no Ceará, no município de Quixeramobim, num lugarejo conhecido como Encantado. Trabalhei na roça até quinze anos de idade. Eu sou o filho mais velho de uma família de onze irmãos. Trabalhei em frentes de trabalho, na época da seca e estudei em cidades próximas desse lugarejo em Quixeramobim e em Senador Pompeu -, porque um padre, progressista da época, me levou para morar com ele e eu era sacristão. Ao mesmo tempo que eu morava na casa paroquial e estudava. Seu nome é João Salmito, não é mais padre, não. Agora é Salmito só. Somos amigos. Eu tinha sido alfabetizado pela minha mãe no interior do Ceará, nesse lugarejo de Encantado. Quando eu terminei o primário, eu tinha que fazer o exame de admissão para receber bolsa de estudo, porque não tinha colégio público. Eu fiz, passei, mas não tinha como morar na cidade. Aí eu fui morar com o padre. Eu tinha direito à comida, à hospedagem e era sacristão. Eu fiquei quatro anos essas condições. Depois eu fui morar em Fortaleza para fazer o colegial, ou científico, e eu precisava correr contra o tempo, aí eu fiz o chamado "Madureza". Entrei na universidade em 1966. Fiz vestibular para filosofia e depois para direito. Nenhuma das duas eu concluí, porque fui expulso pelo AI-5 [Ato Institucional $n^{\circ} 5$, editado em 13 de dezembro de 1968]. Nessa época era também funcionário da IBM, eu trabalhava para sobreviver. Minha experiência em Fortaleza foi muito intensa. Fortaleza, para mim, foi uma passagem, porque eu fiquei quatro anos. Mas foi lá que fui presidente do Centro Acadêmico, fui presidente do DCE, fui denunciado pelas manifestações de 1968, participei de dois congressos da UNE: o de Vinhedo, que elegeu Luís Travassos, e o de Ibiúna, quando houve aquela prisão.

Com a decretação do AI-5 eu entrei na clandestinidade e fui morar em São Paulo. Fiquei clandestino um ano e meio entre São Paulo, Rio de Janeiro e Porto Alegre. Em junho de 1970, eu fui participar da experiência do Araguaia, onde eu morei durante dois anos como lavrador. Lá fui preso - eu era militante do Partido Comunista do Brasil (PCdoB). Fiquei cinco anos como preso político, de 1972 a 1977, cumpri a pena inteira, passei pelos presídios de Brasília, São Paulo e Fortaleza. Fui solto em 1977, mas continuava com os direitos políticos cassados e fui morar em São Paulo. São Paulo oferecia melhores condições para eu sobreviver do que Fortaleza. São Paulo foi a cidade que me recebeu. Tirei carteira de trabalho aqui, em 1977, fui trabalhar em empresas, fui dar aula em cursinho, retomei minha militância política, fui morar com minha companheira, com quem moro até hoje, a Rioco Kayano, que eu também tinha encontrado em 1968 e depois na cadeia. Participei da fundação do Partido dos Trabalhadores (PT), quando eu saí do PCdoB. Disputei a primeira eleição do PT, que foi em 1982, com o Lula, que foi candidato a governador em São Paulo.

Imprevisivelmente fui eleito deputado federal e exerci o mandato de 1982 até 2011, tendo um intervalo de quatro anos quando eu fiquei de fora do Parlamento, porque fui candidato a governador em São Paulo em 2002, tendo ido para o segundo turno - foi a única vez que o PT botou um candidato a governador no segundo turno em SP.

Eu fui novamente processado pelo AI-5 da criminalização da política, que vai ser objeto inclusive desse debate sobre a Constituinte. Eu fui condenado, cumpri pena novamente e, agora, eu estou na terceira quarentena: a primeira foi na ditadura, a segunda na prisão domiciliar com ação penal 470, o chamado Mensalão, e a terceira agora numa quarentena, numa prisão domiciliar por causa da crise sanitária. Eu estou escrevendo uma narrativa sobre a minha vida, desde esses pontos todos, 67-68, passando por toda a minha experiência na guerrilha, na clandestinidade, na fundação do PT, no Parlamento, na Constituinte - foi uma participação muito intensa. Eu vou deixar claro 
aqui, para vocês, como foi esse processo. Agora eu sou militante de ideias. Eu não exerço cargo e nem quero, não exerço mandato e nem quero. Eu sou um militante de ideias e estou fazendo uma reflexão sobre os rumos da esquerda e nossas propostas para o futuro. Me coloco como petista, militante socialista e de esquerda. Eu estou aprendendo, mas não mudo de ideias. A gente muda, mas não muda de lado. A gente continua resgatando aquilo que é universal na esquerda, tirando as lições dos erros e dos acertos, mas assumindo uma militância política, anticapitalista, principalmente na fase atual do neoliberalismo que é o capitalismo financeirizado, monopolista e associado internacionalmente.

\section{Entrevistadores:}

Quando e como você começou a militar?

\section{José Genoíno:}

São três fases da minha militância. A primeira fase foi a militância na Igreja Católica com o padre Salmito. Eu participei da Juventude Agraria Católica (JAC). Ele era de um grupo de padres [progressista], na época não existia a Teologia da Libertação, era o Concilio Vaticano II, e eu participava daquele movimento quando eu morava em Senador Pompeu com ele. A segunda fase foi em Fortaleza. Fui para lá em 1964 para estudar no colégio público municipal. Em Fortaleza presenciei o golpe. No período de 1965/1966 eu abri uma crítica muito ácida contra a Igreja, que eu conhecia por dentro, e uma crítica em relação ao momento em que estávamos vivendo, o pós-golpe. Nessa segunda fase tive contato, juntamente com um grupo de amigos e amigas, com a obra do Sartre, de Camus, com a obra dos filósofos franceses. A gente se considerava existencialista. Isso em 1965. Nessa época, eu era funcionário da IBM. Meu problema era sobreviver, porque eu não tinha quem me mantivesse. Eu tinha que pagar aluguel, comer, etc. A IBM queria que eu fosse um executivo, que eu fosse um jovem preparado para assumir cargos de programação - fui o primeiro operador de computador 1401, que era aquele computador de cartão -, queriam que eu fizesse concurso para a nova geração. Mas eu entrei para a faculdade de filosofia e a IBM queria que eu fizesse economia e administração. Eu disse: "ah, não vou aceitar isso!"

Quando eu entrei na faculdade, iniciei a terceira fase da minha militância. A intensa mobilização dos excedentes em 1966, o efervescente movimento cultural na universidade - inclusive a gente tinha um grupo chamado GRUTA (Grupo de Teatro Universitário) que tinha contato com as várias manifestações culturais da época - e a minha escolha, no sistema de convenção estudantil, para presidente do Centro Acadêmico da Faculdade de Filosofia me levaram a uma militância política engajada. Ali eu me tornei um militante político consciente. Foi nesse período que eu entrei no PCdoB [Partido Comunista do Brasil]. Eu conheci os companheiros do PCdoB em Fortaleza. Esses companheiros, com quem eu tinha uma relação de amizade, de convivência, quando eu fui participar do congresso de Vinhedo, que foi o XXIX congresso da UNE (inclusive um mineiro, de Juiz de Fora, era o presidente da UNE, Luiz Guedes, era quem estava presidindo o congresso e foi quem dirigiu o congresso que elegeu o Luiz Travassos) me chamaram e eu entrei no PCdoB. Nesse momento eu fiz duas opções políticas. Além de entrar no PCdoB, eu tive que me desligar da IBM. A IBM chegou para mim e disse que não dava para eu continuar na empresa participando de manifestações estudantis, e eu era um dos dirigentes da universidade. Ela me propôs que eu fosse para o Rio de Janeiro para fazer um curso de programação de computador, começava uma nova geração dos computadores modernos, e eu disse não. Estava fazendo uma opção muito consciente e não tinha volta. Nesse momento 
também vivi um dilema, porque estava com uma ideia de que tinha que subir na vida, ascender socialmente para tirar minha família da roça, da miséria, mas, também, tinha que fazer isso para milhões de pessoas. Fiz uma opção muito dura, foi demorado. Saí da IBM e passei a morar na universidade. Fui eleito presidente do Diretório Central dos Estudantes, que era correspondente ao UEE [União Estadual dos Estudantes], em 1968.

1968 foi um ano muito intenso. No dia em que foi decretado o AI-5, eu estava na casa de um companheiro do Ceará, o Sergio Miranda, que foi deputado federal por Minas Gerais. A gente disse: "e agora, meu?" Ele disse: "você agora não é mais Genoíno. Está aqui seu nome. Está aqui sua identidade. Se prepara que você agora vai entrar na clandestinidade." Vivi na clandestinidade até ser preso em 1972. Depois de um ano e meio em São Paulo, em junho de 1970 fui para o Araguaia. Eu me lembro dessa data porque foi no dia que a seleção brasileira foi recepcionada no Anhangabaú, [em comemoração] ao tricampeonato [de futebol]. Saí naquele dia que a cidade estava ocupada pela festa, e era o dia ideal para a gente sair, cheguei no Araguaia no dia 25 de julho, data em que é comemorada como o assalto ao quartel Moncada em Cuba. Eu me lembro dessa data porque o Osvaldão [Osvaldo Orlando da Costa], companheiro dirigente da guerrilha, me deu aquela folhinha de calendário do interior, do camponês: "guarda isso aí que é uma lembrança". Fiz isso com muita poesia, com muito sangue, com muita escolha, com muita determinação e, também, risco. Isso não acontece num mar de rosas, tem poesia, sangue e risco.

\section{Entrevistadores:}

Quando você fez essa opção pelo PCdoB e depois optou por essa forma de resistência à ditadura militar, como você lembra que parecia o horizonte?

\section{José Genoíno:}

Em primeiro lugar, a nossa geração, que é a de 1968, foi emparedada pelo AI-5, pelo Estado terrorista. Nós tínhamos três alternativas, somente três, e não mais do que três: ou ia para o exílio; ou era preso na cidade, em casa, e corria risco de morrer; ou ia para a clandestinidade, para luta armada. Só tinha essas três. Não tinha uma quarta. Como eu era militante do PCdoB, conscientemente, - sabendo que o PCdoB preparava a guerrilha no interior do país, diferente da guerrilha urbana - me coloquei a disposição do PCdoB para ir para a guerrilha. Foi uma vontade minha, até porque eu tinha experiência de ter morado no campo, e fiz uma escolha. As duas escolhas que eu fiz foram de livre e espontânea vontade: quando entrei no PCdoB e quando eu fui para o Araguaia.

A saída do PCdoB foi um processo mais traumático. Depois que saí da prisão, em 1978, a gente começou a avaliar toda a trajetória da esquerda na luta armada e eu achava que o PCdoB tinha que fazer uma prestação de contas da guerrilha. Dos quase 70 companheiros que morreram no Araguaia somente dois corpos até hoje foram identificados. Aí também se misturou com a questão do PT, que era um fato novo. Eu vim morar em São Paulo, dava aula em cursinho, participava do Comitê Brasileiro de Anistia (CBA), a solidariedade com as greves do ABC. Entrei em contato com aquela novidade que estava surgindo, então foi quase natural eu me filiar ao PT. Sou o filiado número sete do diretório aqui do Butantã do qual sou filiado até hoje. Moro no bairro Butantã, aqui próximo da Universidade de São Paulo (USP), um bairro classe média baixa, e resido na mesma casa desde 1984, que foi comprada via Banco Nacional de 
Habitação (BNH). Não tenho patrimônio, nem bens. Tenho apenas essa casa em que moro com minha família.

Voltando à sua pergunta, eu fiz essa escolha muito consciente, porque a nossa geração, a de 1968, foi influenciada primeiro pelo clima de revoluções que existia no mundo: as revoluções russas, as revoluções chinesas, vietnamitas, a revolução cubana, a morte do Che, as guerrilhas na América Latina; segundo, pelo intenso movimento cultural que existia à época, e a música que simbolizava isso era É proibido Proibir, do Caetano Veloso; e há também uma movimentação intensa dentro da universidade que era o palco da luta política... maio de 1968 na França, no México, no Brasil. Foi um movimento muito intenso. Quando veio o AI-5 aquela vanguarda estudantil de 1968 foi emparedada. A questão de ir para a luta armada foi quase um pulo. Tanto que a gente costumava dizer, depois da avaliação, que estávamos mais preparados para morrer do que para matar. Foi uma escolha de muito heroísmo, de muita vontade, até porque a gente estava num beco sem saída. Quer dizer, as intensas manifestações de 1968 produziram a situação de que não tinha muitas saídas. Alguns foram para o exílio, outros presos. Fui preso só em 1972. Fiquei no Araguaia durante quase dois anos.

Costumo dizer que minhas escolhas, todas elas, foram livres e conscientes. Não fui conduzido. Mesmo naquelas em que eu corri mais risco, como por exemplo: ser candidato a governador que eu sabia que não dava para ganhar, era em nome de um projeto coletivo. A questão de ser presidente do PT, que eu não queria, eu gostava muito de ser parlamentar. Sempre adotei a visão de que o projeto é coletivo, não é individual. Isso fiz no PCdoB. Fiz na guerrilha. Fiz na clandestinidade. FIZ NA CADEIA quando eu fiquei cinco anos preso. Coletivamente participei de greve de fome, de rebeliões, de várias tentativas de sair da cadeia e nenhuma deu certo. Sempre era coletivo e continuo acreditando em um projeto coletivo como militância de esquerda. Sempre na minha vida quando fiz escolhas, nunca fiz pela metade. Escolhi $100 \%$, com riscos, com prejuízos e até com correção monetária e juros do dia. Nunca fiz escolhas pela metade: clandestinidade, luta armada, cadeia... eu topava qualquer movimentação.

A minha formação como militante de esquerda foi muito influenciada por esse clima de 1968. Aliás, não é só de 1968, foram as gerações dos anos 1950 e 1960 . Aquelas duas décadas foram marcantes na história da esquerda porque foram momentos que as flores desabrocharam. Tudo desabrochava: comportamental, politicamente, teoricamente, familiarmente. Por exemplo: abandonar a faculdade e não me formar para mim foi natural. Aliás, o meu pai antes de morrer - morreu com 96 anos - me fez as seguintes perguntas: Você queria ser doutor, entrou na universidade e a política lhe tirou? Você queria sair da roça para estudar e voltou para roça para fazer guerrilha? Você vira deputado federal conhecido e não fica rico em São Paulo (imagina, um homem do interior, analfabeto, vê o filho na televisão em São Paulo e não fica rico)? Vocês ganharam a batalha contra o governo, elegeram o Lula e você está nessa situação (isso foi logo após o mensalão)? Você está punido. Eu respondi: é o destino. Mas foi difícil botar na cabeça de um camponês que o destino é tão contraditório.

\section{Entrevistadores:}

Voltando aos anos de 1970, você conta que atuou no CBA. Foi lá que você começa a ter contato com os sindicalistas, com os católicos, ou seja, com os grupos que estiveram no momento da formação do PT?

\section{José Genoíno:}


Eu primeiro entrei em contato com o Comitê Brasileiro de Anistia, tendo participado de vários congressos, de várias reuniões, inclusive eu tive contato com vários companheiros como o Nilmário Miranda, de Minas Gerais, como a dona Helena, também de Minas Gerais, a Madre Cristina, aqui em São Paulo, e, também, com expresos políticos. O segundo encontro foi com o movimento de Eucaristia e com os Comitês de Solidariedade das Greves do ABC, isso em 1978. Nessa época eu era professor de cursinho, dava aula de história. Era a maneira de sobreviver. O cursinho Equipe me aceitou sabendo de tudo de minha vida, mas eu não podia falar para os alunos. Isso foi até uma coisa interessante, comecei a dar aula em 1977 e em janeiro de 1979 o jornal Estado de São Paulo publicou grandes reportagens sobre o Araguaia. Até então ninguém sabia de onde eu tinha vindo - os alunos, já os professores sabiam. Um dia entro em sala e estava lá todo mundo com o jornal e minha cara estampada nele. Foi um trauma na sala de aula. Teve de tudo que você possa imaginar. Foi muito interessante a minha experiência de dar aula no Equipe. Fiquei cinco anos lá e gostava de dar aula porque resgatava uma experiência de 1967, 1968 - na verdade, os cursinhos nasceram dos Centros Acadêmicos que davam aula de graça para os vestibulandos e depois virou uma indústria de cursinho. Comecei a dar aula de história para vestibular porque não exigia documento nem título. Eu costumava dizer que meu título era passar o pessoal no vestibular, o resto não interessa. $E$ foi interessante porque quando fui candidato a deputado federal tinha muitos alunos que eu tinha dado aula durante cinco anos, que estavam espalhados nas universidades de São Paulo e foi esse pessoal que fez minha campanha para deputado federal em 1982.

Em 1980 tive contato com Lula. Fazia parte daquelas reuniões, mas era um contato muito provisório, inicial. Eu não era do núcleo do $A B C$, era dos Comitês de Solidariedade. Aí a gente começou a participar das articulações para formar o PT. Minha relação com o PCdoB já estava tensionada, porque eu estava fazendo uma opção por outro partido.

\section{Entrevistadores:}

Mas você entra no PT com uma dissidência do PCdoB, que era o PRC.

José Genoíno: É. Antes do PRC, eu era de uma dissidência que se chamava Esquerda do PCdoB. A esquerda do PCdoB defendia que o partido convocasse um congresso para discutir a questão do partido, do programa e a própria avaliação do Araguaia. Nós fomos afastados, criamos uma tendência chamada Partido Revolucionário Comunista (PRC) e atuamos no PT. Surgiu um debate sobre a história de duas camisas no PT, porque a gente tinha uma visão de que o PT era tático. Até tive um diálogo com o Lula, uma vez eu Ihe perguntei: "Lula, seu partido é tático ou estratégico?" e ele disse: "não me interessa. Quero um partido dos trabalhadores. Não me interessa se é tático ou estratégico." Até hoje ele cobra isso de mim.

A Constituinte teve um papel muito intenso na minha formação. Durante a Constituinte eu era militante de uma ala de esquerda do PT, que representava um tensionamento com o que era a maioria do PT na própria Constituinte. Mas, ao final da Constituinte, pela experiência que vivi, fui fazendo uma espécie de revisão política. Porque a gente entrou na Constituinte com a ideia de que era só para marcar posição. Mas a gente deu conta de que estava fazendo uma Constituição para o país. Uma Constituição que tinha conquistas, ambiguidades, impasses. Então isso também influenciou na minha militância política, que sempre sofreu os reflexos do ambiente político que atuei como militante, como dirigente ou como deputado. 


\section{Entrevistadores:}

Em sua primeira legislatura, de 1983 a 1987, você participou do debate sobre a Constituinte?

\section{José Genoíno:}

Eu acho que há um cenário que é muito interessante a gente levar em conta para efeito de transcrição da memória. Primeiro eu vou colocar uma preliminar para vocês. Eu sou radicalmente contra essa interpretação da Constituição como se fosse uma exegese hermenêutica de juristas. A Constituição é um pacto político, fruto da luta de classes, do confronto político e das escolhas que se colocam dentro da correlação de forças. E vivi muito isso. A minha primeira legislatura foi muito isso. O primeiro impacto foi as Diretas. A primeira grande frustação do país foi a derrota da emenda Dante de Oliveira no Congresso Nacional, que tem a ver com a democratização do país. Com aquela transição por cima, que eu chamo "transição fraudada, inconclusa ou transição recalcada", que tinha como ponto central a Lei de Anistia, da qual nós éramos críticos. Inclusive nós não defendíamos a Lei de Anistia, apesar de sermos beneficiados por ela, de participar da anistia ampla, geral e irrestrita, a gente discutia uma revisão da Lei de Anistia.

Na primeira legislatura, tivemos um enfrentamento radicalizado no Congresso de como votar os decretos salariais do Delfim Neto: a votação ou começava pela Câmara ou pelo Senado. Era decreto-lei, não tinha medida provisória. Se começasse pela Câmara, que era o correto, a gente ganharia. Se começasse pelo Senado eles ganhariam "eles" era a ARENA - e houve um embate radicalizado. A gente montou um grupo no Congresso, de uns trinta deputados - tinha PT, PCdoB, PMDB, estava o Artur Virgílio, João Herman, por exemplo, além dos do PT - e a gente fez um pacto "se mudar o regimento a gente vai ocupar o plenário e tomar a sessão na marra" e montamos um esquema físico. Era um nível de radicalização política! Mas a gente ganhou a parada com o então oligarca Nilo Coelho, que atendeu a nossa questão de ordem. Aí, a ditadura já estava com muitas fissuras, com muitas divergências.

Aí veio a campanha das Diretas e a gente participou intensamente. Na campanha das Diretas a gente viveu o dilema que está colocado para a democracia brasileira. Eu nunca esqueço, em um comício da Cinelândia, quando o Tancredo (eu ia em todos os comícios. Tinha a lembrança de 1968 e para mim os comícios das Diretas eram, além de ir aos jogos do Corinthians e ver a massa, um regaste dos cem mil, dos trinta mil, de 1968, então aquilo ali me fazia bem emocionalmente), com um milhão na Cinelândia, disse para o Ulysses: "essa multidão não cabe no Colégio Eleitoral, como vamos fazer se a emenda Dante de Oliveira não passar?" Quer dizer, ele já estava com um pé nas Diretas e um pé no Colégio Eleitoral. A queda das Diretas na Câmara foi uma grande frustração e eu acho que o PT agiu corretamente em continuar a campanha do "Só Diretas". Aliás, o primeiro comício do "Só Diretas" foi feito em Belo Horizonte. O único artista que topou participar foi o Gonzaguinha, com Lula, com os deputados do PT. Depois teve a disputa pelo Colégio Eleitoral, o PT tinha oito deputados, três saíram por causa do Colégio Eleitoral, ficamos com cinco. O PT teve a coragem política de marcar posição. Ficamos muito isolados, mas era fundamental para ser a ala esquerda da transição pactuada no Colégio Eleitoral. Veio a posse do Sarney e o Plano Cruzado, também fomos contra. Marcamos posição e sofremos também muitas críticas. O PT foi contra aquele Plano Cruzado e sofreu também muitas críticas. A morte do Tancredo [Neves] foi a segunda grande frustração do país, porque ele simbolizava aquilo que a música do Milton Nascimento [Coração de Estudante] 
retratava. Ele morreu, assumiu a presidência o Sarney e botou o nome de Nova República.

Eu era deputado do PT e tive o seguinte episódio com o Ulysses Guimarães. Nós fizemos um documento relatando as torturas, as mortes e os nomes dos 234 torturadores e ele foi publicado em um jornal alternativo chamado Em Tempo. Pedi a transcrição daquele documento nos Anais do Congresso. O Ulysses Guimarães me chama no gabinete dele (primeira vez que me encontrava no gabinete do Presidente da Câmara, era um deputado que veio da guerrilha, da prisão, um ser estranho naquele Congresso Nacional) e diz: "menino, você cutucou o leão com vara curta". Nessa época eu era menino, tinha 36 anos. Aí eu disse: "mas não é Nova República?" Ele retrucou "mas não teve eleição direta para presidente". Aí eu disse "nem o senhor foi eleito presidente". Aí o velho se derreteu um pouco e eu disse para ele: "olha, doutor Ulysses, eu não poderia deixar de registrar esse documento porque eu sou o único deputado que assinou esse documento quando eu estava preso e na medida em que a Nova República estabeleceu a imunidade parlamentar, não posso me omitir e vou transcrever esse documento". Ele respondeu "eu entendo". Ele montou um cenário para responderem a minha provocação e apliquei a lição da guerrilha. Na guerrilha você tem que conhecer o cenário da guerra. Como eu estava no Congresso Nacional, tinha que conhecer o cenário do Congresso para sobreviver e conhecia muito o regimento interno já naquela época. Eu disse "então você me dá a palavra", e ele disse "eu dou". E eu disse "não quero só falar, quero que o documento seja transcrito porque é um compromisso com a história" e ele "vamos combinar o seguinte: você não pede isso e daqui a quinze dias você vem aqui e deixa o documento na minha mesa que vai ser transcrito". Fui chamado de revanchista. O Pimenta da Veiga, de Minas Gerais, foi o primeiro a me responder, era o líder do governo Sarney. Falou o deputado, também meu amigo e preso político Ailton Soares, e usei a palavra depois sempre usava a palavra depois porque já conhecia o regimento. Foi o primeiro acordo que eu fiz com Ulysses Guimarães, em 1985.

Depois desse episódio teve a Comissão Especial que fez a convocação da Constituinte. A Constituinte foi convocada por uma emenda constitucional chamada Congresso Constituinte e dizia o seguinte: o Congresso eleito em 1986 terá entre as suas funções normais a de elaborar a nova Constituição do país. O PT não tinha vaga para votar nessa comissão especial. Mas deputado podia participar de qualquer reunião do Congresso com direito a voz e eu participava dessa comissão especial para falar. Eu defendia, o PT defendia, uma Constituinte exclusiva e nós até nos articulamos com Flavio Bierrenbach, que era deputado do PMDB e fez um relatório pela Constituinte exclusiva. Mas ele perdeu, nós perdemos. O relator que elaborou a emenda do Congresso Nacional Constituinte foi o Walmor Giavarina, do Paraná. Então o primeiro embate da Constituinte foi sobre a convocação para o Congresso Constituinte.

Na eleição de 1986, a do Congresso Constituinte, o PMDB teve a grande maioria porque elegeu o maior número de governadores, de deputados e senadores por causa do Plano Cruzado. Para o PT foi uma eleição muito difícil. O Lula foi eleito deputado federal, foi o mais votado de São Paulo e do Brasil, mas a campanha foi muito delicada para o PT. Teve o episódio do assalto ao Branco do Brasil em Salvador, que foi atribuído a uma corrente do PT. Ali foi um massacre - um massacre contra o PT não é novidade. Eu, como deputado federal, participei junto com Djalma Bom de um ato de solidariedade aos boias-frias, na cidade de Leme, pois mataram um casal de boias-frias e botaram a culpa nos deputados do PT. Para se ter uma ideia, em 1982 fui eleito com 58 mil votos, a minha votação em 1986 se reduziu a 28 mil votos. Só entrei porque o 
Lula puxou a votação para cima, porque ele teve mais de 700 mil votos. Então a eleição para a Constituinte foi em um quadro de crise. Era a crise do Plano Cruzado, era a crise do governo Sarney - as manifestações contra o governo Sarney eram intensas -, a crise das frustrações que vinham da morte do Tancredo e dos decretos salariais que foram revogados. Havia um vazio político muito grande. Para onde vai a transição? A grande sabedoria do Ulysses Guimarães foi dizer o seguinte "ou eu trago tudo isso aqui para dentro do Congresso Nacional ou então esse negócio vai se quebrar", porque o Executivo deslegitimado que era o governo Sarney com o fracasso do Plano Cruzado, o Judiciário não tinha esse protagonismo que tem hoje.

$\mathrm{Na}$ instalação da Constituinte eu fiz uma manifestação questionando ser o presidente do Supremo a presidir a sessão. Pedi a palavra pela ordem no grito e disse que ele não tinha autoridade para instaurar a Constituinte porque o poder emana do povo. Que quem deveria instalar a Constituinte eram os presidentes dos partidos, os eleitos. $\mathrm{E} o$ Ulysses Guimarães me manda uma manifestação escrita à mão que dizia: "deputado Genoíno, manifestei-me ao ministro Moreira Alves favorável à sua manifestação. Ulysses Guimarães". Aí se iniciou um embate que vai se manifestar em vários momentos dos trabalhos da Constituinte.

\section{Entrevistadores:}

Como se dava esse debate interno ao partido vinculado a figuras como Raymundo Faoro?

\section{José Genoíno:}

É importante registrar, para efeito da memória política do país, que o movimento de massas era por eleições diretas já. Depois o Tancredo transformou aquilo no "Mudanças Já", que era a justificativa para o Congresso eleitoral. Não houve um movimento de massa pró-constituinte, como, por exemplo, agora está acontecendo no Chile. Não houve! A partir da derrota das Diretas, da crise do governo Sarney e do risco de retrocesso político, todas as forças políticas do país - os três segmentos principais eram à direita que vinha da ditadura militar, o centro hegemonizado pelo PMDB e a esquerda, que era na época PT, PCdoB e PDT, e que era minoria começaram a se posicionar sobre a Assembleia Nacional Constituinte.

A gente defendia uma Assembleia Constituinte exclusiva. Nesse sentido fizemos aliança com a OAB, que na época era presidida pelo Faoro, e perdemos. Depois o PT criou uma comissão especial em que participava o José Eduardo Cardoso, eu, Marco Aurélio Garcia, o Fabio Comparato e produzimos um Projeto de Constituição. Nós o protocolamos na instalação da Assembleia Nacional Constituinte em fevereiro de 1987 [o deputado mostra um exemplar do documento Partido dos Trabalhadores à Assembleia Nacional Constituinte]. Portanto, tinha uma comissão do PT para Constituinte. A orientação do Diretório Nacional do partido era muito crítica às possibilidades da Constituinte: primeiro porque era uma Constituinte Congressual, com senadores biônicos e tudo mais. Segundo se falava em comissão dos notáveis. Então a ideia era simplesmente marcar posição - eu até tenho um documento aqui que chamo "Exigências para a Constituinte", na época foi feito por mim e pelo PRC, em que eu apresentava que o nosso trabalho na Constituinte era marcar posição e impedir a legitimação da ordem burguesa capitalista.

Só que quando nós entramos o que aconteceu - e é por isso que eu acho que a Constituinte não é a coisa de sábios nem hermeneutas, é produto da luta de classes naquele quadro político, os movimentos sociais (de mulheres, indígenas, negros, 
trabalhadores, CONTAG, MST, os movimentos democráticos da classe média, da intelectualidade) começaram a jogar as suas pautas no Congresso Constituinte. Aí qual foi a nossa tática? Foi mudar o caráter do Congresso Nacional Constituinte. Primeiro foi mudar o nome: não é mais Congresso Nacional Constituinte é Assembleia Nacional Constituinte. A segunda posição do PT foi na instalação questionar o ministro Moreira Alves, e isso coube a mim porque da bancada era quem tinha mais experiência, já conhecia os manejos regimentais e eu fiz esse questionamento. Terceiro, a gente iniciou uma batalha de questionar os senadores biônicos, porque eram os senadores que vinham do Pacote de Abril, e depois iniciamos uma batalha de não aceitar uma comissão de notáveis. Tomamos uma posição contra a comissão de notáveis. A Constituição tem que começar do zero. E o que significava começar do zero? Aí é que foi o desafio. Não pode ter pré-condição. Era maioria absoluta. Ficaram os [senadores] biônicos, mas era maioria absoluta.

Aí começamos um debate, intenso, com questão de ordem, logo após a instalação da Constituinte - você tinha a Câmara funcionando e a Constituinte, mas na prática era só a Constituinte - que era o seguinte: os poderes da Constituinte são soberanos. Ela pode decidir sobre tudo: do mandato do Sarney ao sistema de governo. Enfim, o Brasil podia ser decidido e discutido pela Assembleia Nacional Constituinte. Ela era soberana. Era o Poder Constituinte Originário. A gente começou a discutir essa tese e eu participava dessa discussão de maneira muito intensa, porque eu já vinha com a minha experiência do primeiro mandato da bancada do PT. Então a ideia da Constituinte Originária, a ideia da soberania, a ideia de partir do zero, nós fizemos uma certa aliança com o centro, que era principalmente o Ulysses Guimarães, Mário Covas, também o Fernando Henrique Cardoso, e tinha também a direita neoliberal que era Roberto Campos, Delfim Neto, essa turma aí. Nós fizemos uma aliança com o centro primeiro porque eles tinham maioria, resultado da eleição de 1986 e do Plano Cruzado; segundo, eles sabiam que se aquele cenário não fosse viável a crise ia se aprofundar. Fizemos um acordo pontual, por exemplo: o regimento interno, que o relator foi o Fernando Henrique Cardoso, nós dissemos que as emendas produtos da sociedade com 30 mil assinaturas deviam ser recepcionadas pelo Congresso Constituinte e seus líderes teriam direito a voz na Assembleia Constituinte. Isso foi uma grande vitória! Porque nos trouxemos a pressão popular para o lado da esquerda (movimento dos sem-terra, CONTAG, mulheres, índios, movimento negro, sindicalistas). Esse movimento veio com a emendas populares. Eu até hoje tenho as fotografias dos líderes indígenas, da luta do Caó, da Benedita [da Silva] para criminalizar o preconceito racial, a discussão da bancada do batom (pela primeira vez entrou no Congresso a bandeira feminina da luta das mulheres chamado a bancada do batom).

Quando o Brasil viu que tinha um cenário ali, ele foi. O período de 1987 a 1988 foi o de maior mobilização popular em Brasília de maneira contínua. Eu acho que o Ulysses Guimarães teve uma sensibilidade muito grande porque ele disse o seguinte "eu tenho que trazer todo mundo pra cá, porque se não for aqui aonde é que vai ser?" E ele dizia para nós nas negociações o seguinte "vamos botar todo mundo aqui dentro, um dia entra os engravatados e outro dia entra o pessoal da sandália havaiana". E a gente dizia "tudo bem, entra o pessoal da UDR [União Democrática Ruralista], da FEBRABAN [Federação Brasileira dos Bancos], mas você tem que botar o pessoal dos sem-terra aqui dentro". Aí topamos fazer um acordo. "Então bota todo mundo", e ele teve essa compreensão política de botar todo mundo ali dentro. Então a crise econômica, a crise social, a crise política, tiveram um canal de tratamento político e institucional que foi a Assembleia Nacional Constituinte. Fomos fazendo algumas conquistas, por exemplo: 
estabelecemos, com esse regimento interno aqui, uma ideia que foi o Diário da Constituinte durante cinco minutos durante o Jornal Nacional. Não era a Voz do Brasi!! Eram cinco minutos às oito horas [da noite] para divulgar os trabalhos da Constituinte. Botamos nesse regimento interno como é que a Constituinte tinha que ser elaborada. A Constituinte tinha dezesseis subcomissões [há um lapso de memória do entrevistado, foram 24 subcomissões]; essas dezesseis viravam oito comissões, e essas oito comissões viravam a comissão de sistematização, depois é que iria para o plenário. $\mathrm{E}$ nós dizemos o seguinte: o que seria apreciado será o que vier desse processo. Portanto, ninguém apresenta emenda global de Constituição.

Conseguimos conquistas importantes com esse regimento interno que foram, principalmente, as emendas populares, a maneira como a Constituição iria ser formada e a soberania dela para decidir sobre tudo (de Forças Armadas ao Poder Judiciário, das relações de propriedade até a ampliação da Lei de Anistia). Portanto, abriu-se uma pauta que a gente ia questionar a transição pactuada ou fraudada. Três correntes se expressavam na Constituinte: a esquerda, o centro e a direita. A força da esquerda era a relação com a sociedade, a participação popular que se manifestou através das emendas populares. A classe dominante estava dividida, que não se dividiu nas questões econômicas, mas nas questões sociais, políticas, direitos individuais se dividiu. Com essa divisão nós tivemos força a partir da nossa aliança com os movimentos populares organizados que vinham do fim da ditadura. A transição pactuada ou fraudada no Brasil teve duas vertentes: a vertente institucional, por cima, e a vertente social, por baixo. A nossa força foi uma aliança com a vertente social, que vinha do PT, das greves, do Movimento da Eucaristia, das Comunidades Eclesiais de Base, do CPP, do movimento de reconstrução da UNE. Todo esse processo desaguou na Constituinte, numa aliança com as forças de esquerda naquele processo. Acho muito interessante para a gente entender como essa Constituição que passou a ser interpretada como a hermenêutica dos especialistas, teve desidratada o caráter político de classe, de confrontação, que foi sua feitura. Isso é um pacto político!

\section{Entrevistadores:}

Nesse sentido o [presidente José] Sarney mesmo durante a discussão do regimento interno da Assembleia não vai ter um papel importante? Porque quando você fala "a gente vai legislar sobre tudo... o mandato do presidente". Essa foi uma questão bastante controversa e o governo atuou com bastante força?

\section{José Genoíno:}

Fizemos uma aliança com o Ulysses Guimarães. O Ulysses Guimarães, chamado por nós de tri-presidente: presidente da Câmara, presidente da Constituinte e presidente do PMDB, e ele disputava com o Sarney. Ele não era bem ligado ao Sarney. Então nós dissemos o seguinte "Ulysses, vamos fazer um regimento interno para trazer tudo aqui para dentro". Fizemos um acordo com ele, pontual. A interferência do Sarney na Constituinte se deu no tamanho do mandato [do presidente], na questão das comunicações, na questão das Forças Armadas, na questão do Poder Judiciário - que até hoje não mudou. Foi nisso aí. No funcionamento da Constituinte ele não interferiu porque o Ulysses Guimarães era o presidente da Constituinte e disputava com ele, e era legalmente o vice-presidente da República. Lembra que eu falava da força do Ulysses? Então, soubemos aproveitar essa nuance. Agora a interferência dele [do Sarney] foi violenta na discussão sobre o sistema de governo.

\section{Entrevistadores:}


Você falou algumas vezes sobre o regimento e sempre foi conhecido por dominar bem o regimento da Câmara. Você começou a investir nesse conhecimento do regimento no seu primeiro mandato? Foi pensando na Constituinte?

Quando eu cheguei [na Câmara], em 1983, um deputado de Minas, o Zé Bonifácio (Bonifácio Andrada, filho do José Bonifácio) - um deputado de direita, mas a gente tinha uma relação muito respeitosa, uma relação muito intensa - e o Airton Soares disseram "você vem da guerrilha e da clandestinidade e aguenta um mandato na crista da onda como ex-guerrilheiro e ex-preso político, mas isso passa. Se você quiser ser deputado para valer, entre na Casa com tudo. Domine o regimento interno. Vá para Comissão de Constituição e Justiça. Saiba negociar e seja o primeiro a chegar e o último a sair da Casa". Na Constituinte cheguei a dormir no gabinete para poder ser o primeiro a entregar as emendas. O que eu fazia? Nós, da esquerda, fazíamos para o mesmo tema três tipos de emenda: emendas para marca posição, emendas para aprovar e emendas para negociar. As emendas eram apreciadas pela ordem de protocolo. Cheguei a dormir algumas noites no gabinete e cinco horas da manhã eu estava na fila. Eu pegava as emendas sobre Forças Armadas, sobre direitos e garantias, sobre aborto, sobre união estável... sobre tirar Deus da Constituinte. Fiz essa proposta. Eu queria tirar "sobre a proteção de Deus" em nome do estado laico e essa emenda teve que ser apreciada primeiro porque eu apresentei.

Eu conhecia o regimento interno e eu resolvi o seguinte "ou eu sobrevivo conhecendo o regimento interno ou então não dá". Depois eu me especializei mais e cheguei à conclusão "eu sou minoria, mas impeço a maioria de votar". Estabeleci até uma regra, uma espécie de manual de obstrução, que eu chamava "obstrução selvagem". A Constituinte era o palco para isso porque não tinha acordo de lideranças, era tudo por ordem de chegada: chega entra, chega entra. Então eu aprendi que não é você decorar o regimento. Você tem que saber o que você quer e conhecer a Casa para poder usar aquelas normas para o teu objetivo político. Foi isso que acabei me especializando. Eu participei do regimento interno da Constituinte. Fiz o regimento interno da Câmara depois da Constituinte. Por isso eu conhecia bem o regimento, porque participei da realização dele, sabia onde estava o caminho das pedras. É politizar e não decorar, você tem que saber o que quer para fazer a disputa política. Isso me ajudou muito e ajudou a bancada do PT no Congresso Constituinte.

O Congresso Constituinte foi a grande experiência política da democracia em que a política comandou. Hoje a política é submissa ao Judiciário, é submissa à investigação, é submissa à mídia. Na Constituinte era o contrário. A política era aquilo que a Hannah Arendt fala "a política é a ação livre dos humanos para criar possibilidades". A política é a ação que depende da inteligência, da força e da capacidade de negociação. A gente fazia uma aliança com o Ulysses Guimarães, que eu acho o último liberal da história do brasil, e ele dizia "para mim a política tem solução para tudo. Eu odeio a ditadura porque a política tem solução para tudo. Tudo a gente busca solução na política". Tiveram vários episódios na Constituinte em que ele mostrou isso, como aquele primeiro episódio comigo que foi a transcrição dos nomes dos torturadores. Então foi um período muito rico. Não havia essa deslegitimação da política, de denúncia, e olha tinha toma lá dá cá, é dando que se recebe.

Para vocês terem uma ideia do nível de interferência do governo Sarney no período da Constituinte: de 1985 a 1988, portanto da posse do Sarney até a promulgação da Constituição, durante três anos, foram outorgadas 1.082 concessões de rádio e televisão. Olha! De 1934 a 1979 foram outorgadas 1.483, do Estado Novo até 1979 e 
em três anos foram 1.082. Dessas concessões é que surgiu o monopólio oligárquico das TVs comerciais com 270 geradoras da TV Globo - só para a TV Globo 124; rádios 3600 AM, FM 11 emissoras, 61 afiliadas. Quem era o ministro das comunicações? Antônio Carlos Magalhães, e aqui era o Sarney. Essa foi a força total que gerou o centrão, que dominavam a Comissão de Sistematização na Constituinte e tinham os seguintes objetivos: o mandato do Sarney, que começou defendendo seis anos e depois passou para cinco - perdemos o mandato de quatro anos em uma votação que misturou com o sistema de governo que era parlamentarismo ou presidencialismo - e as comunicações sociais. Portanto, o mandato foi a grande interferência do Sarney. A primeira grande interferência do Sarney na Constituinte. Dos 91 constituinte que receberam concessões, 82 votaram nos cinco anos do Sarney. Então, a interferência do Sarney foi fundamental na questão dos cinco anos, depois veio a questão das comunicações.

\section{Entrevistadores:}

Como foi a escolha para ir para essa subcomissão da defesa: você que optou por ela ou foi uma decisão partidária?

\section{José Genoíno:}

O PT tinha dezesseis deputados e tinham dezesseis subcomissões [como dito foram 24 subcomissões], cada um iria para uma subcomissão e era por afinidade. O Plinio de Arruda Sampaio, que vinha do Ministério Público, foi para a subcomissão do Judiciário. Eu, pela minha experiência, fui para subcomissão de Defesa e Segurança Pública. O Paulo Delgado, que era de Minas Gerais, de Juiz de Fora, foi para subcomissão de Direito Eleitoral. O Eduardo Jorge, que era do SUS, dos médicos sanitaristas, foi para a subcomissão de Previdência e Saúde. A Bene [Benedita da Silva] foi para a subcomissão de Direitos e Garantias em razão da questão racial; o Olívio Dutra para a subcomissão do Trabalho e Direitos Sociais, o [Luiz] Gushiken, que vinha dos bancos, para a subcomissão de Finanças e Tributação, o Vladimir [Palmeira], que tinha mais uma formação de economista, foi para a subcomissão de Economia. Na subcomissão de Educação era o Florestan [Fernandes], Meio Ambiente era o Vitor Buaiz. Estou me lembrando desses nomes. Aí era mais ou menos natural.

Eu fui para a subcomissão da Defesa e perdi todas as propostas. A gente abriu o debate sobre a questão do artigo 142 - esse artigo que está até hoje pautando o que eu chamo de tutela e autonomia militar que é "em nome da lei e da ordem". O artigo 142 foi o único que provocou uma crise com os ministros militares. Ela foi inicialmente relatada pelo [Ricardo] Fiúza, que era extrema-direita e depois presidida pelo Jarbas Passarinho. Então havia controle total da Subcomissão de Defesa do Estado, da Sociedade e de sua Segurança. Isso não ocorreu em outras subcomissões. A Subcomissão de Direitos e Garantias, uma subcomissão importante, era o [José Paulo] Bisol. A Subcomissão de Saúde e Seguridade, dos médicos sanitaristas, era o Almir Gabriel, que era do PMDB, indicado pelo [Mario] Covas. O que o Covas fez? Ele indicou para relatores das comissões e das subcomissões nomes que tinham uma posição centro-esquerda porque seriam membros da sistematização: Almir Gabriel, Bisol, Cristina Tavares na Comunicação, o Oswaldinho [Osvaldo Lima Filho], lá de Pernambuco, que foi ministro da agricultura do [presidente João] Goulart para relator da Subcomissão da Reforma Agrária; Plínio [Arruda Sampaio] foi da Subcomissão do Poder Judiciário; o João Hermann, que era do PMDB, foi para Subcomissão da Nacionalidade, da Soberania e das Relações Internacionais. Na subcomissão enfrentamos o debate sobre Forças Armadas e perdemos todas. Perdemos 
particularmente o artigo 136, que é o que define a decretação de estado de defesa; perdemos o artigo 142 que é a lei e a ordem e o artigo 144 que trata da segurança pública.

Outro tema que nós perdemos foi do Judiciário. O Plínio ficou como relator na Subcomissão e perdeu. A gente defendia o Tribunal Constitucional. Mudava a terceira instância para Tribunal de Justiça e para o Tribunal Constitucional para avaliar as questões constitucionais. Extinguia o Superior Tribunal Militar e a justiça militar. Criava a questão dos mandatos no caso do Supremo e estabelecia um mecanismo de controle público - não o que existe hoje de Conselho Nacional de Justiça ou o Conselho Nacional do Ministério Público. Esse relatório do Plínio foi derrotado na Subcomissão e o Judiciário ficou intocável. Aí surgiu o grande problema, que eu chamo o grande monstro constitucional, que foi o Ministério Público com poder soberano sobre todos e tudo. O capítulo do Ministério Público foi orientado por pessoas do Ministério Público que tinha história na esquerda: no caso do Plínio, do Hélio Bicudo, do Sepúlveda Pertence, do Ibsen Pinheiro. E qual era a fundamentação? Era um órgão de estado para se confrontar com a tutela militar que estava expressa no artigo 142. Veja bem aonde chegamos! Então, o capítulo do Ministério Público como um superpoder teve o aval da esquerda. A gente excluiu o tema do juiz de instrução, que era o modelo italiano de o processo de inquérito ter um juiz de instrução, em nome do fortalecimento do Ministério Público. Então o Ministério Público passou a ter superpoderes dado pelo constituinte sem nenhum tipo de controle. Quer dizer, o sistema de freios e contrapesos não chegou nele. Chegou no Judiciário, mas o Judiciário é um outro capítulo.

A gente discutiu a relação do Legislativo com o Poder Judiciário ao tratar da competência do Senado Federal. Como o Senado Federal aprova a indicação do ministro do Supremo, foi incluído um artigo que depois foi considerado inconstitucional. Um absurdo: um artigo da Constituição ser considerado inconstitucional! Ele diz que é "competência de o Senado suspender a execução, no todo ou em parte, de lei declarada inconstitucional por decisão definitiva do Supremo Tribunal Federal". Então, quando o Supremo Tribunal Federal considerar uma lei aprovada pelo Congresso como inconstitucional, o Senado pode suspender a execução. É o Senado que suspende. Veja bem como era avançado isso aqui. Disseram que houve uma mutação constitucional e com isso virou letra morta o inciso 10 do artigo 52 da competência do Senado Federal. Para vocês terem uma ideia de como a gente vai nas entranhas da disputa política.

Eu acho que o sistema de poderes foi totalmente deformado. Hoje vocês têm uma supremacia do poder judicial sobre o Poder Legislativo muito violenta, e até sobre o Poder Executivo. Eu costumo dizer que, hoje, existe três poderes: o poder da toga, o da farda e o da mídia. Esses três poderes derrubam quem quiser. A supremacia do Judiciário é tão grande que suspende mandato - acabou de suspender o mandato de um senador -, cassam mandato de eleito pelo povo - de governador, dois; cassou um senador na época da lava-jato. Essa supremacia do ativismo judicial, que nega a soberania popular, nós não tocamos. Além de não mudar as competências do Supremo, a lei orgânica da magistratura que vem do pacote de abril do governo Geisel é a mesma até hoje. E mais ainda, quando se promulgou a Constituição, o Supremo Tribunal Federal adotou uma ação de descumprimento do preceito constitucional de que as suas competências foram recepcionadas pela nova Constituição. Uma loucura! Quer dizer, eles consideraram que as suas competências foram recepcionadas pela Constituição, mas são eles quem decidem isso, e não o Congresso. A construção dos 
poderes ficou muito maculada por uma questão conjuntural que foi a duração do mandato do Sarney e a questão do sistema de governo. O sistema de governo foi remetido a um plebiscito para saber se era monarquia ou não; o mandato de cinco anos do Sarney foi aprovado em uma decisão polêmica que teve de tudo. Teve tapas, beijos - na época era sucesso a música Entre tapas e beijos do Leandro e Leonardo - e foi aprovado o mandato do Sarney e esses dois núcleos centrais ficaram intocáveis: o poder das Forças Armadas e o poder do Poder Judiciário.

O terceiro núcleo foi a comunicação. A relatora do capítulo da comunicação social era a Cristina Tavares, que elaborou o relatório dela e a ABERC derrotou. Quando derrubou, dissemos publicamente que a $A B E R C$ não iria aprovar o relatório dela porque a gente entrava num sistema de obstrução - pela primeira vez a gente chamou de obstrução selvagem. Não tinha votação. Teve quebra de microfone, cuspida na cara ... teve de tudo, mas não tinha relatório contra a deputada Cristina Tavares. O Ulysses Guimarães disse "vai ter um buraco negro". Então chamou todo mundo para o gabinete dele e negociou o capítulo da comunicação social. Os princípios todos, na forma da lei. Ninguém tinha a maioria e ficaram todos os princípios. Estão lá o conselho de comunicação, fim dos monopólios, fim das propriedades cruzadas, etc. na forma da lei. E esse "na forma da lei" nunca foi regulamentada. Um dos nossos erros, quando governamos o país, foi não enfrentar essa questão do aparato de comunicação do país que é um oligopólio familiar. Um conglomerado que domina a política no Brasil. Só ver o que é o papel da Globo, agora da CNN, dessas repetidoras e tal. O capítulo da comunicação foi violento.

O quarto problema foi o da reforma agrária. Perdemos por um voto porque um deputado faltou e a UDR ganhou por um voto. Teve, inclusive, revólver na mesa. Nós fomos para várias alternativas, uma delas era constitucionalizar o estatuto da terra que veio da ditadura militar. Perdemos e a questão agrária do país ficou da seguinte maneira: é cláusula pétrea o direito de propriedade, pode desapropriar com a função social, mas tem que pagar o valor justo em dinheiro. Então, dependendo o juiz não tem desapropriação. Esse é o impasse que existe até hoje na questão das relações de propriedade no campo. O quinto episódio foi a questão da anistia. O constituinte incorporou a Lei da Anistia no ato das discussões transitórias. Nós apresentamos uma emenda sobre o crime de tortura, o terrorismo e o crime de racismo e está no capítulo dos direitos e garantias individuais. Houve uma disputa intensa. A gente queria tratar esses crimes separadamente e a direita queria juntar. Ela ganhou. Quando juntou a gente colocou três condições para esses crimes: são crimes insuscetíveis de anistia, inafiançáveis e IMPRESCRITÍVEIS. Era exatamente para dizer que a Anistia não poderia cobrir os crimes contra a humanidade porque botava a palavra imprescritível. A palavra "imprescritível" foi objeto de uma votação dramática no plenário. Nós perdemos, mesmo compondo a esquerda com o centro, que era o Mario Covas, líder do PMDB à época. Esses foram os impasses, as encruzilhadas que a Constituinte viveu.

\section{Entrevistadores:}

Voltando à Subcomissão de Defesa, como operou a pressão externa das Forças Armadas? E como essa pressão externa se deu em relação à continuidade da militarização da Polícia Militar?

\section{José Genoíno:}

As Forças Armadas tinham um ministro do Exército que era muito forte, o Leônidas Pires Gonçalves. O general Leônidas Pires comandava uma assessoria [Assessoria 
Parlamentar do Gabinete do Ministro do Exército] muito competente de militares, comandada por um general na Constituinte. Era uma assessoria técnica, com a presença direta e, é claro, tinham maioria nessa comissão. Então, as emendas sobre o papel das Forças Armadas, sobre segurança pública, sobre o artigo 136, nós perdemos todas, no voto. Eles mobilizavam os deputados, havia uma articulação. Eles prepararam uma assessoria tecnicamente competente. Um exemplo de como isso se manifestou. Quando fomos preparar os relatórios das comissões para ir para o plenário da Sistematização, descobrimos - porque a gente conhecia tudo ali., todas as veredas, caminhos e picadas do Congresso Nacional - que se [estava] fazendo uma revisão no relatório antes dele entrar no PRODASEN, que era a gráfica que imprimia o relatório. Fomos lá eu, o Vivaldo Barbosa, do PDT, o Haroldo Lima, do PCdoB, e o Bernardo [Cabral] estava reunido com o [Nélson] Jobim, o Fernando Henrique Cardoso, com o [Antonio Carlos] Konder Reis, o Adolfo de Oliveira, que era representante o lobby dos cartórios do Rio de Janeiro. Nós entramos lá, porque a gente entrava em tudo quanto é lugar, não tinha limitação, e dissemos "temos uma proposta para as Forças Armadas sobre o artigo 142, que tínhamos perdido na subcomissão. A gente está reapresentando uma emenda do então senador Fernando Henrique Cardoso que tirava lei e ordem". Eu defendia só defesa externa, não tinha poderes constitucionais nem lei e ordem. Eu disse "fazemos uma concessão" - usávamos uma tática: emenda para marcar posição, emenda para aprovar e emenda para negociar, eram três tipos de emenda. Eu disse "temos uma emenda para negociar", que era a emenda do Fernando Henrique Cardoso. Aí o Fernando Henrique Cardoso disse "essa emenda é minha, mas eu não estou mais defendendo". Eu disse "mas Fernando Henrique Cardoso ela está protocolada, ela deixa de ser sua e vai ser nossa agora". Era nesse nível o debate político. E defendemos essa emenda. Aí o Bernardo Cabral disse "eu achei interessante"! Porque o Bernardo Cabral era um relator geral que não queria se desgastar e nós sacamos isso. Aí o Fernando Henrique Cardoso disse "isso vai dar confusão"! Aí os outros disseram "o problema é do relator". O relator botou o artigo 142 sem lei e ordem e imprimiu o relatório para ir passar no plenário. Aí deu uma crise militar. Foi quando o Leônidas, o ministro da Marinha e o da Aeronáutica fizeram um pronunciamento, com o apoio do Sarney, dizendo que a Constituinte estava desfigurando as Forças Armadas. Isso foi em uma sexta-feira, fim de semana, crise militar, até se falou em juntar militar. O Ulysses Guimarães foi entrevistado e perguntaram "você não teme uma junta militar?" E disse "a última vez que teve a junta militar no Brasil foi a junta dos três patetas." Ele chamou a provável junta militar de junta de três patetas. Deu nas manchetes de jornais. O Ulysses fazia isso, batia duro e depois negociava. Deu uma crise feia. O Leônidas que era o avalista da transição - que comecei falando dela -, cobrava essa questão. Aí o Ulysses chamou o pessoal no gabinete dele e fez a seguinte proposta "eu boto a emenda do Fernando Henrique Cardoso, mas só se um dos Poderes convocar" (o Fernando Henrique Cardoso topou, aliás foi ele que fez a proposta). Por isso que ficou "a defesa da lei e da ordem a convocado por um dos Poderes", que é o rabicho do artigo 142. Vou ler aqui que é para não ter dúvida sobre o quanto isso é importante e porque até hoje está alimentando essa polêmica. Esse aqui é o rabicho - a gente chamava de rabicho - que foi objeto de uma disputa intensa nos bastidores. Está aqui: "142 - a garantia dos poderes constitucionais e por iniciativa de qualquer destes, da lei e da ordem". O Brasil só tem duas Constituições que não tem lei e ordem, que é a Constituição do Império, a de [18]24 e a Constituição de [19]37, do Estado Novo. Todas as constituições têm a concepção de lei e ordem. Ordem é tudo e Lei é tudo. E isso foi uma disputa intensa, fomos para o plenário e eu defendi, em nome do PT, do PDT e do PCdoB - e isso está 
gravado nos anais da Constituinte - que aquilo era uma porta aberta para a tutela militar. De certa maneira não é por acaso que depois de mais de trinta anos esse tema do 142 volte à tona.

A questão da segurança pública vinha com o 136, que é pouco discutido. E o 136 é grave também, porque diz: "o presidente da República pode decretar estado de defesa para preservar ou prontamente estabelecer a ordem em locais restritos ou determinados". A gente foi contra isso aqui. Aí vem para o artigo 144, que é o da segurança pública. Houve uma disputa sobre o conceito de segurança pública. Defendíamos na subcomissão que a segurança pública tivesse como função a defesa da vida, da sociedade, dos direitos e do patrimônio. Mas foi tirado da sociedade e dos direitos... ficou da vida e do patrimônio. Portanto, a concepção de segurança pública, que é o artigo 144, foi mantida a ideia de que a segurança pública acaba sendo uma arte de guerra. Segundo ponto da segurança pública, que é o parágrafo sexto do artigo 144, que diz que as PMs são forças auxiliares e reserva do Exército. Terceiro que perdemos foi a unificação das polícias. Perdemos essa emenda no artigo 144 da Constituição. Portanto, este item da segurança pública foi também um debate. Nesse debate a esquerda ficou sozinha, era PT, PDT e PCdoB, inclusive quando eu defendia essas emendas no plenário. Aliás, recentemente a Folha [de São Paulo] publicou a transcrição desse embate no plenário da Constituinte, quando eu fiz a defesa da proposta, porque eu já tinha um acúmulo que vinha da comissão temática que eu era o representante do PT. O centro todo fez coro com essa questão do artigo 142. Com isso eu estou dando um painel dos temas polêmicos e cruciais que diz respeito ao Estado na Constituinte. Foram esses temas que levou o PT a fazer uma declaração de voto simbólico na redação final da Constituinte, e que durante muito tempo disseram que o PT não tinha assinado. O que é uma mentira. O PT assinou! Eu guardo até hoje ali na minha mesa o fax das assinaturas do PT. O PT assinou! Agora, fizemos uma declaração de voto por causa desses itens que estou me referindo.

\section{Entrevistadores:}

Como é que era o trabalho cotidiano na subcomissão? Como é que eram escolhidos os convidados?

\section{José Genoíno:}

Como na transição política o acordo foi possível por cima, mas por baixo houve grande mobilização social. As comissões mais intensas eram trabalho, saúde e previdência, direitos e garantias, o sistema de governo, por causa da polêmica de cinco anos do mandato do Sarney, comunicação, reforma agrária. Eram comissões que tomavam a pauta, a mídia e as atenções. Já essas comissões de Estado - vamos chamar assim, por exemplo do Poder Judiciário - eram os especialistas do direito. A questão das Forças Armadas conseguimos chamar algumas pessoas, mas nós tínhamos acúmulos de especialistas. Chamamos o presidente da $O A B$, chamamos os juristas (foi o Marcio Thomaz Bastos, chegou a ir o Faoro), mas não tinham grande cobertura da mídia. 0 foco eram as questões sociais por causa da crise e onde tinham movimento de massas. Nessas questões de Estado não tinham movimentos de massas. A maioria das pessoas que foi convidada era do status quo militar. Nós chamamos algumas pessoas que pensavam diferente, tipo o [Geraldo] Cavagnari [Filho], o Eliéser Batista, que era da Unicamp. O enfrentamento era o seguinte "aqui eu perco todas, não ganho em nenhuma". Era tudo mesmo. Convocar era muito difícil. Portanto, era a comissão do status quo: defesa do estado, Forças Armadas e segurança pública. Não havia um foco. Isso tem muito a ver com o fato de o Brasil não ter construído uma elaboração 
teórica - eu tentei fazer isso, mas muito limitadamente - sobre a questão da defesa, das Forças Armadas. Elas consideram que era assunto só delas, não era dos civis. Então, a gente começou a chamar alguns setores da academia, que era basicamente da Unicamp, o pessoal da Universidade de Brasília, mas eram pessoas que não marcavam posição. Por exemplo, quando se fala de previdência e saúde na época, você tinha o movimento nacional - é bom deixar isso claro - do SUS, pessoal. O SUS nasceu dessa época, era um embate. Para vocês terem uma ideia, o Carlos Santana, que era líder do governo Sarney, ele era favorável ao SUS. Ele dizia: "a saúde pública eu defendo. Eu sou favorável ao Sarney nesse ponto, mas no SUS não". Eu estou dando um exemplo. Carlos Santana que era um deputado do PDS. Então, essa questão... quando mexia com a educação a aliança com a igreja quase tremia porque a Igreja defendia as PUCs, o ensino confessional... Aí a gente estabeleceu o seguinte: 0 sistema de educação era público, privado e estatal. Então, eram negociações dramáticas, não eram fáceis. Já esses temas [da subcomissão de Defesa] envolviam pouca gente. A própria questão da anistia mobilizou os militares. Eu acho que é o artigo oitavo, das disposições constitucionais transitória, que era para incorporar os militares cassados na lei de anistia, que não estavam na lei original, e destacamos a palavra imprescritível para discutir nos termos dos direitos e garantias individuais. Então, veja bem, no tema dos direitos e garantias individuais. A bancada das mulheres, começou a comunidade LGBT com a orientação sexual, nem era o termo união estável, a questão indígena eram temas que chamavam mais atenção. Esse tema institucional era pouco debatido, e a própria cobertura midiática era pequena. Se você olhar a Folha de S. Paulo no que diz respeito a cobertura do artigo 142, papel das Forças Armadas, encontra uma frase que eu disse: "a lei e ordem cabe tudo, até a ordem capitalista". O que que é ordem? O capitalismo é ordem, o status quo é ordem. Essa discussão, que vem da eleição americana e aqui essa nova direita extremada, além da ordem... Esse tema foi muito forte no plenário, mas não tinha cobertura midiática. Tanto que o pessoal brincava comigo "você está metendo a cara nesse negócio, isso aí não dá voto e se tiver golpe você tá fodido" Desculpe a palavra, mas era assim.

Eu fui me especializando em vários temas. Por exemplo, eu discutia Forças Armadas, discutia justiça, discutia direitos e garantias, discutia o direito de a mulher interromper a gravidez, eu discutia a união estável, eu discutia direito autoral, eu discutia a descriminalização da maconha. Eu discutia todos os temas. Eu entrava em todas as comissões para discutir esses temas. Acabei construindo uma certa universalidade para os temas da Constituinte. Tanto que nos anais da Constituinte para todos esses temas eu tinha emenda que eu apresentava na hora: as emendas que eu fazia da descriminalização da maconha até a união civil, a orientação sexual. Uma vez eu estava fazendo o debate sobre orientação sexual, uma deputada olhou para mim e disse "mas por que você defende isso? Estou olhando para você...", "O que você tá olhando?", "pois é, mas eu estou achando estranho, você é um homem normal". Eu disse "eu sou um homem normal. Por que eu não posso discutir esse tema?" Para vocês terem uma ideia de como era o preconceito. Tem que levar em conta uma situação: a gente resolveu botar o Brasil de cara na Constituinte. Quer dizer, o Brasil mostrou a sua cara na Constituinte. Tudo apareceu, nada ficou escondido. Tudo apareceu. Se pega as fotografias, os anais... eu costumo dizer que, historicamente, o Brasil mostrou duas vezes a sua cara: na Constituinte e no governo Lula. Conferências, cotas, população indígena, tudo apareceu. Tu-do! E a Constituinte foi isso. Por isso, inclusive, que houve um debate radical sobre a Constituinte que está presente até hoje. A direita não aceitou a Constituinte porque disse que o Brasil era ingovernável. 
Tenho aqui a primeira versão da Constituição que tem uma introdução do Ulysses, depois tiraram esse discurso de improviso dele, em que ele chamou a Constituição Coragem. Nesse discurso, que é bem curto, ele vai falando "o homem é o problema da sociedade brasileira: sem salário, analfabeto, sem saúde, sem casa, portanto, sem cidadania". E ele vai, vai, aí chega em um ponto e diz "por isso a Constituição nasce do parto de profunda crise que abala as instituições e convulsionam a sociedade". Aí ele diz "por isso mobiliza, entre outras, novas forças para o exercício do governo e administração dos empasses. O governo será praticado pelo Executivo e pelo Legislativo" ele não cita Judiciário. Está aqui o discurso dele na promulgação. Perguntei para ele, eu já tinha uma relação muito próxima dele, "doutor Ulysses por que você não citou o Judiciário?" Ele disse "no fundo no fundo não é poder, é órgão de Estado, porque lá não tem rampa". Ele usou a figura do Niemeyer: a rampa quer dizer que o povo sobe e desce. O Parlamento tem rampa. O Planalto tem rampa. O Judiciário não tem rampa, porque lá não é poder da soberania popular. Eu acho que é a soberania popular que dá a última palavra." Veja só a consciência do Ulysses Guimarães! Parece que ele estava adivinhando o que viria a acontecer no Brasil com essa nova ditadura que acontece de outra forma. E ele falou isso. Nesse discurso ele diz "quem é que vai resolver os impasses? O Poder Legislativo e o Poder Executivo". Que é a soberania popular. Depois esse discurso dele foi tirado das edições da Constituição de [19]88, evidentemente. Estou só mostrando como esses empasses foram muito ricos desse ponto de vista e, ao mesmo tempo, tem a ver com a posição do PT.

O PT mudou o país e foi mudado pelo país. Costumo dizer que o povo muda o PT e o PT muda o povo. É uma relação dialética. O que aconteceu conosco? Nós entramos na Constituinte e fomos observando que estava mudando, por exemplo, direitos e garantias: o conceito de cláusulas pétreas para direitos e garantias individuais, prisão em segunda instância, habeas data, direito de imagem, direito à privacidade, sentença transitada e julgada. E colocamos um artigo que é pouco comentado dizendo o seguinte "o poder emana do povo e será exercido diretamente ou nos termos da Constituição, ou diretamente." Foi a primeira vez, no Brasil, que a Constituição coloca que o poder é exercido diretamente pelo povo, porque tem plebiscito, referendo e a consulta popular. Isso foi um embate pesado. Depois vamos para o artigo sete que são os direitos sociais: perdemos 40 horas, mas ganhamos 44; perdemos estabilidade no emprego, mas ganhamos dispensa motivada. Aí a gente começou a sentir que estava mudando. Fomos para o capítulo da saúde e da previdência, a grande conquista que foi a construção do Estado de Bem-Estar Social. Neste item fizemos a primeira distribuição de renda no brasil quando estabelecemos para os trabalhadores rurais o salário-mínimo básico, transformando o fundo rural em salário-mínimo. Isso foi objeto de uma crítica profunda, que agora o líder governista diz que a Constituição só tem direitos, não tem deveres. Esse sempre foi o discurso da direita. Então veja bem, a questão das garantias, a questão dos direitos sociais, a questão do Estado de BemEstar Social financiando políticas públicas - previdência, saúde e assistência social -, o capítulo da educação. Introduzimos duas coisas novas na Constituição: o direito das populações originarias - esse debate está posto agora no Supremo que está para discutir o caráter temporal das populações originarias, e a questão do meio ambiente que pela primeira vez entrou na Constituição. O conceito de família que não depende do casamento. Na própria ordem econômica era um capítulo que recuperava o papel do estado na economia. Houve uma aliança com setores nacionais e militares, e a questão central era o conceito de Empresa Brasileira, que depois foi alterado pelas reformas neoliberais do governo Fernando Henrique Cardoso. 


\section{Entrevistadores:}

Como você sentia esse discurso econômico liberal na Constituinte? E como era essa aliança com os militares?

\section{José Genoíno:}

Esse discurso do liberalismo econômico era minoritário. Era levado a público principalmente pelo Roberto Campos, pelo Delfim Neto, pelo Luís Eduardo Magalhães e algumas outras figuras, mas era minoria. A maioria acabou defendendo o quê? A nacionalização dos serviços essenciais, por isso que houve a questão do gás, portos, a questão do petróleo, a questão das telecomunicações - a Embratel, etc. - e a questão do papel planejador-indutor do Estado. E a questão sensível era o conceito de Empresa Brasileira, que era aquela constituída por maioria de acionistas brasileiros. Essa emenda foi mudada e qualquer empresa estrangeira que entra aqui passa a ser brasileira com todos os incentivos. Isso é um problema no caso da defesa nacional. Por isso quando o Fernando Henrique Cardoso ganha a eleição em [19]94, o conjunto das emendas econômicas que apresenta, com o discurso de fim da Era Vargas, era petróleo, gás, a questão das telecomunicações e o conceito de Empresa Brasileira. Nessa época, eu era deputado e tentei dialogar com o Sergio Motta, "vamos salvar a Embratel. Vamos criar para a Embratel o mesmo estatuto da Petrobrás como empresa pública aberta". Por quê? A Embratel tinha dois satélites e o Brasil privatizando a Embratel perdia os satélites. Essa discussão sobre os satélites está hoje aí. Perdemos essa votação na emenda que privatizou o sistema de telecomunicações. Essa foi a primeira ofensiva de desfigurar a Constituição. A primeira grande ofensiva!

A segunda grande ofensiva foi com o golpe de 2016, com a PEC 95, porque na hora que você estabelece o teto de gastos como cláusula pétrea ferrou. É a PEC da Morte, que tem a ver com a crise do SUS. Acaba com o SUS através do teto, assistência social, etc. Esse foi o segundo grande assassinato da Constituição! O terceiro foi a relativização dos direitos e garantias individuais com a reinterpretação do que é segunda instância, e acho que se fizerem uma emenda mudando a segunda instância isso vai ser a eliminação do conceito de cláusula pétrea. O conceito de cláusula pétrea tem a ver com a constituição alemã pós-nazismo. Na Constituição está artigo 60, no parágrafo 4, que as chamadas cláusulas pétreas não podem ser mudadas por emenda constitucional, só através de uma assembleia constituinte. Foi com base nesse dispositivo que evitamos que a pena de morte fosse incluída na Constituição. Eu estou só mostrando a gravidade desse ataque às cláusulas pétreas.

Costumo dizer que com a violência da mudança na ordem econômica, com a mudança da PEC 95, com a mudança da questão do financiamento das políticas públicas, que é o Estado de bem-estar social, com a terceirização e a precarização que acaba com o artigo sete e deixa de ser cláusula pétrea, se relativiza o artigo quinto a Constituição vira uma manequim exposta na prateleira e sem conteúdo. Ela não tem conteúdo, ela é desfraldada, ela é desfalcada, ela é assassinada. E coloca um dilema para a democracia. Como vamos reconstituir o pacto constitucional no Brasil? É esse dilema que está posto. Por quê? Porque os três pilares do poder político no Brasil que são: 1) as Forças Armadas, a Constituição garantiu; 2) o Poder Judiciário, se autoproclamou como protagonista de uma ordem que não coloca em risco os contratos, o capital nem as relações de propriedade. Não tem uma decisão do Supremo que coloca em risco as relações contratuais do sistema financeiro, dos monopólios e oligopólios. Nenhuma! Eles até se dão o luxo de discutirem a chamada pauta identitária, mas discutir relações econômicas e de direito, não; 3) o monopólio midiático, que é cada vez mais intenso. 
Essas três vertentes impedem a governabilidade. Por exemplo, se elege um cara, como nós elegemos, contrário a esses interesses eles derrubam. Derrubam! A mídia de um lado, o Ministério Público de outro, e o Judiciário de outro não se salva ninguém. Porque ganham a população com uma narrativa de combate a corrupção. Criam uma concepção autoritária de cruzada moralista e em nome dessa concepção autoritária...

Nós inoculamos o veneno da serpente, porque não tivemos clareza do que estava se firmando com a crise que a esquerda passou a viver com o fim do Muro [de Berlim], da União Soviética. No embate político, acabamos depositando nas carreiras de Estado (incluindo o Ministério Público, as altas burocracias da Advocacia-Geral da União, e a Justiça Federal) um poder que desidrata a política. A política, aquilo que é do conflito, da luta de classes, passa a ser uma gerência dos mercados. Como se diz, o estado de direito passou a ser substituído pelo mercado de direitos. Aí tem um impasse, no meu modo de entender, que é o que estamos discutindo. Essa Constituição para mim, que participei intensamente, conheço ela de cor porque eu sei onde está o artigo, não esperava que fosse tão violentamente violentada como foi. Em questões nucleares foi a emenda FHC da ordem econômica. Foi o golpe - na hora que você dá um golpe sem crime de responsabilidade, ferrou, e foi o que aconteceu em 2016. Na hora que você prende sem sentença transitada e julgada, ferrou o artigo $5^{\circ}$. Na hora que você, em nome da ordem, da onda, você quebra o preceito da garantia (a coisa mais absurda do mundo é você fazer uma divisão entre juiz garantista e não garantista, é da natureza do judiciário a garantia, a divisão é garantista porque o judiciário é contra majoritário. A concepção de judiciário é contra majoritário). Mas o que aconteceu? Acho que isso não está presente na Constituinte. Acho que é um grande dilema que é o constitucionalismo americano. Entrou aqui com o fim da Guerra-Fria e, principalmente, os episódios das Torres Gêmeas, introduziu o direito penal do inimigo - que bebeu no Carl Schmitt: existe até um livro que chama Direito Penal do Inimigo - e introduziu um punitivismo judicial. Esse punitivismo judicial faz o que bem entende. Não tem limite, em nome de uma causa maior. Estamos nesse impasse. Esse é o principal impasse da democracia brasileira, além do impasse que é a questão dos direitos sociais, da radicalização da crise social que está em curso.

\section{Entrevistadores:}

Como a queda do Muro de Berlim e o fim da União Soviética impactaram a sua trajetória, a sua visão da Constituinte e da Constituição, e a esquerda?

\section{José Genoíno:}

Isso me impactou muito, porque eu vinha da luta armada, da resistência, e quando abraçamos a luta democrática e principalmente a vivência na Constituinte achamos que a democracia no Brasil era para valer. Eu me surpreendi com o que aconteceu. Em primeiro lugar porque os acontecimentos do Leste Europeu, da União Soviética e outras experiências revolucionárias marcaram muito a nossa geração. Muitos companheiros, que a gente convivia, morreram acreditando que aquilo ali era $100 \%$ correto. $\mathrm{E}$ a gente entrou em um desafio monumental que era o seguinte: como resgatar a história da esquerda - que, no meu modo de entender, vem de [18]48 com o Manifesto Comunista -, e fazer uma autoavaliação, sem jogar a água, a bacia, o sabonete e a criança fora? Como fazer esse equilíbrio, que é como um carro com retrovisor e para-brisa? Isso marcou muito a esquerda. E eu fui muito influenciado por isso. De um lado, tivemos uma grande vitória que foi a Constituinte, a Constituição, porque participamos dela. De outro, eram os dilemas do novo discurso da esquerda. Por isso que acabamos centrando a nossa visão política numa eleição do presidente 
Lula, que foi de [19]89 até 2002. Esse foi o centro da nossa política. E aí o que aconteceu? Qual foi a avaliação que faço hoje? Nós fizemos uma avaliação de que as instituições do Estado estavam democraticamente consolidadas. Isso foi uma avaliação equivocada. Essas instituições, que criticamos na Constituinte, não passaram por uma mudança estrutural. Devíamos ter feito mudança no sistema político, nas Forças Armadas, na segurança pública e no Judiciário e não fizemos quando ganhamos o governo. Mais do que isso, entramos em um dilema: achamos que dava para mudar a ordem por dentro da ordem, mas chegamos à conclusão que só por dentro da ordem não dá. Estão aí os exemplos da Bolívia e do Chile de que se você não tiver mobilização popular, soberania popular, se não tiver movimento social organizado só por dentro da ordem não muda. A gente usava uma expressão que era ter dois pés: um pé na luta social e um pé na luta institucional. Não era voltar a luta armada porque ninguém defendia isso. Só que quando a gente ganhou a eleição o que ganhou foi o pé da luta institucional e fomos absorvidos. Fomos cooptados! A história mostra que quando você ganha um governo e não muda as estruturas de Estado ou você será derrubado - que foi o que aconteceu no Brasil, na Bolívia, no Chile que agora está se recuperando - ou você é cooptado. A classe dominante brasileira é uma classe extremamente reacionária e conservadora. Sofremos um golpe preventivo. Uma contrarrevolução preventiva porque não ameaçamos ninguém. Não ameaçamos ninguém! Fizemos uma política reformista, de baixa intensidade, com muita conciliação e eles deram um golpe preventivamente. Por quê? Porque o caráter de classe da burguesia brasileira não aceitava aquelas medidas: de bolsa-família, empregada doméstica, inclusão social, salário-mínimo, desenvolvimento econômico, geração de emprego, nem isso... Porque o modelo econômico da financeirização, dos oligopólios, da dependência aos Estados Unidos falou mais alto. Então, acho que esse dilema começou a existir quando vivemos o governo FHC e ele legitimou a ordem neoliberal com as privatizações. Ficamos só resistindo, só resistindo, e sofremos três derrotas pesadas: duas que foram as de 1994 e de 1998, e uma, muito pesada, que foi a de 1989 e que gerou um impeachment. Por outro lado, entrou na agenda política um moralismo constitucional, que é uma faca de dois gumes. Sou crítico desse moralismo constitucional porque a gente substituiu o confronto de classe, o confronto programático, por uma moralidade que enxergava o mundo, a sociedade, como se fosse um jardim de Éden, em que os homens bons e a mulheres boas vão construir o bem comum. Não é bem assim! E os conflitos? E os interesses? Então acho que depositamos numa visão equivocada no sistema de justiça, no sistema de investigação. Achamos que os direitos da Constituição fossem ser garantidos pelo Judiciário e não pela luta social. Então, ao invés da gente ficar presos à institucionalidade, tínhamos que ter nos dedicado à luta social organizada. Esse foi o dilema que a gente viveu naquele período, porque você tinha uma ofensiva ideológica fim da luta de classes, fim da história (o Fukuyama revelou o fim da história quando veio a derrubada das Torres Gêmeas: opa, aquilo da história não deu certo, nem a luta de classes), estado mínimo, privatização, e austeridade fiscal. Veio uma ofensiva muito grande. Naquela ofensiva a gente não se contrapôs com uma alternativa. Um exemplo disso, e lamento que fui minoria total, o projeto ficha- limpa, que acho que é um projeto autoritário e é errado, teve o aval da bancada do PT, inclusive teve um dos relatores. Eu fui voto vencido porque achei que quem decide quem é limpo ou sujo é o povo. É o princípio da soberania popular que fala mais alto, não é o juiz. A tragédia do projeto da ficha-limpa é que ele é algo para manter o Lula fora da disputa política, que é a única liderança popular que pode disputar um projeto popular e democrático. Veja bem a tragédia! E o PT deu aval para aquela coisa. Além das leis que compuseram essa ofensiva do 
lavajatismo, que constrói uma concepção política autoritária: lei da delação, lei das organizações criminosas, lei de terrorismo. Que foram lavras do nosso governo, para deixar muito claro! Elas dão um arcabouço legal para esse protagonismo que fundamenta uma visão autoritária das relações políticas, quer dizer, da política como produto da luta de classes, dos conflitos, da negociação. Por isso a Constituinte foi o grande exemplo da primazia da política. Lá a gente negociava com todo mundo. Discutia tudo, mas a política predominava. Agora não! Agora você recorre ao juiz, recorre a isso, recorre aquilo. E um editorial do Jornal Nacional é uma orientação do Comitê Central dos capitalistas de como a sociedade deve se organizar. Esse é o dilema que estamos vivendo. É um novo tipo de autoritarismo, eu acho que estamos vivendo um autoritarismo chamado por alguns de furtivo: um autoritarismo constitucionalizado, legalizado, por dentro. Ele vai corroendo por dentro. Destrói e ocupa. E mobiliza uma base política que não disputamos, que é uma base do senso comum com uma postura revanchista em relação à Nova República, à Constituinte e ao período em que governamos. Essa base raivosa, que o capitão mobiliza, vem desse revanchismo do senso comum que prega morte, preconceito contra mulher, contra negro, contra índio. Governamos, mas sem disputar hegemonia. Nós nos iludimos que dava para governar só com as medidas sociais e econômicas. E a hegemonia? E os corações e mentes, como é que fica? Essa é uma lição dura para uma esquerda que resistiu a luta armada, que sobreviveu (somos sobreviventes, sobreviventes), que entrou na luta democrática $100 \%$ e que foi espirrada por uma ordem econômica monopolista e politicamente autoritária. Faço esse dilema com muita dor porque vivi intensamente a Constituinte. Achei que ali, finalmente, tínhamos feito uma revolução no Brasil. Finalmente!" Aquele ato simbólico de votar o impeachment da Dilma [Rousseff] homenageando o principal torturador, aquilo ali fala por si só. Quer dizer, os laços da Nova República, que eu mostrei aqui que foi pactuada pelas Forças Armadas, foram desfeitos. Da Nova República, do Tancredo e do Ulysses, imagina da Constituinte? Então, qual é o nosso problema? Estamos vivendo uma nova era, uma nova era, ninguém sabe o que virá, mas não é mais a era da democratização da Constituinte. Temos que construir outros paradigmas. É um dilema brutal!

\section{Entrevistadores:}

Como foram as conversas do PT com as entidades da sociedade civil que não percebiam o caminho institucional como o caminho de luta?

\section{José Genoíno:}

Houve um divórcio! Houve um divórcio entra a luta institucional e a luta social. A Constituinte foi vitoriosa porque fundiu a luta social com a luta institucional, depois foi se separando. Começou com a questão do impeachment do Collor - acho que foi um problema, pois para viabilizar aquela cruzada moralista tinha que ter instituições do Estado elitista. E surgiu uma questão complicadíssima para a esquerda e para esse divórcio: certas carreiras de Estado, que tem o saber e a técnica, passam a ter uma supremacia em que o poder não emana do povo. Esse é o problema central. A soberania não emana do povo, emana dos saberes da alta burocracia. Tanto que nesse discurso ideológico surgiu a meritocracia, surgiram as agências reguladoras, surgiram os bancos centrais independentes como uma nova instância de poder. Não enfrentamos uma reforma democrática que colocasse a fusão da soberania popular, que essas entidades da sociedade civil. Por exemplo, houve um divórcio da intelectualidade progressista com a institucionalidade pós-Constituinte. A intelectualidade se refugiu na academia; os partidos se refugiaram no Congresso e no 
Executivo e houve um divórcio. Esse divórcio, no meu modo de entender, impediu que a gente mobilizasse soluções alternativas que estão postas agora. Isso se agravou quando o PT ganhou a eleição, porque havia um problema de governabilidade, tínhamos que realizar reformas que eram no sentido social. Veja bem, qual foi o nosso pepino? Desprezamos as reformas de Estado. O poder político, que é o centro da luta pela democracia, foi deixado de lado. Achávamos que esse problema estava resolvido, e não está. Esse divórcio foi se acentuando e, inclusive, acho que o exemplo mais claro disso foram as manifestações de 2013, quando você tem algo parecido com uma negação da política, que foi hegemonizado pelos aparatos midiáticos. A gente não fez uma disputa política que mediasse o não-divórcio. E aí se colocou um problema para a democracia. Como a gente elaborou na Constituinte a democracia precisava dar conta de outras demandas. Hoje não dá para falar em democracia sem botar o direito das mulheres, sem botar o direito da comunidade negra, sem botar o direito da população originaria, sem botar o direito da comunidade LGBTQIA. Porque senão essa chamada pauta identitária - que eu não chamo pauta identitária - é trabalhada por setores do capital, da direita, e a separa da luta anticapitalista. Esse é um dilema, e nós não compreendemos isso. Por outro lado, a democracia representativa ficou disfuncional com as reformas neoliberais. O sistema econômico quer segurança dos contratos, quer previsibilidade. Se você liga a televisão ... O mercado não vota, mas derruba o governo. Então, veja bem, como isso se coloca o desfiguramento da política. A covid e a crise sanitária recolocaram a política. Por incrível que pareça a tragédia recolocou a política no centro. Ou a política busca uma solução para isso ou então a humanidade corre risco: com a crise sanitária, a crise ambiental, a crise cultural e, principalmente, a crise social. Então isso é um problema. É um problema que começou quando esse divórcio não foi enfrentado com a elaboração de novos paradigmas da esquerda. Eu participei desse processo, faço uma autoavaliação disso, porque diz respeito aos dilemas de como construir um novo programa, um novo modelo de organização. $A$ organização fabril, sindical, está em crise. Não tem mais aquela velha classe trabalhadora que originou o PT. Hoje você tem o trabalhador informal, o trabalhador de aplicativo, você tem o trabalhador doméstico. Você tem uma situação inteiramente nova que temos que elaborar. Hoje o centro da organização é por área territorial, por cidade, por bairro. Enfim, é um problema novo que está colocado. Houve uma reestruturação capitalista para resolver o problema da acumulação e para resolver os problemas dos fundos sociais e dos direitos sociais (que revogou o artigo sete, a reforma da previdência, etc.). Portanto, estamos diante de um desafio monumental, que é a própria radicalização da democracia. A própria radicalização da democracia! Defendo o socialismo dentro de uma visão libertária e democrática, mas qual é o tipo de socialismo que nós defendemos? Então são dilemas de uma crise virtuosa para a esquerda. Não podemos ter medo da crise. Esses problemas começaram no período do Fernando Henrique Cardoso e do discurso neoliberal. O que era? Fim da Era Vargas, Estado de menos e não de mais, o mercado, a globalização como um bem em si. A globalização, que veio com a ideia muito forte de que a sociedade não queria mais conflito, criou essa sociedade do medo, a sociedade do fantasma e em vez do conflito, [ele] foi substituído por uma espécie de sociedade do consumidor. Você é sujeito pela metade, você é consumidor do que te oferecem, você não pode dizer um não $100 \%$. Criou-se uma ideologia que é mais ou menos o seguinte: uma hecatombe pode destruir a humanidade, um vírus ou um terremoto, mas o capitalismo é eterno. Criouse o capitalismo como uma religião eterna para os humanos. É imbatível e não é verdade. Então, esse dilema é crucial para uma esquerda socialista e radicalmente democrática. Acho que é o repensar que estou propondo, tirando essa avaliação do 
processo político constituinte que a gente viveu, que atravessou esse dilema do fim da Guerra-Fria e o início do modelo neoliberal - que começou com a ofensiva Margareth Thatcher e Reagan, depois vieram as privatizações, a crise das Torres Gêmeas e a crise de 2008. Não é brincadeira, é um processo muito violento.

Deixa-me falar, estou fazendo uma narrativa da minha vida que eu estou concluindo na pandemia. Não é contar história, é narrar minhas lições na experiência toda que relatei para vocês. Tenho uma memória oral e não da escrita. Aprendi a ser da oralidade desde o movimento estudantil, passando pelo Parlamento. Nunca fiz um discurso lendo, sempre faço pelo improviso. Para mim a questão da memória é questão de militância. Para mim a memória é subversiva, é presente e futuro. A gente tem que saber de onde a gente vem, o que somos e para onde vamos, principalmente nesse momento de trevas em que a gente está vivendo. A gente tem que ter a luz no fim do túnel e eu estou na descoberta, estou tentando. Estou atormentado. A minha vida é isso. É o que tenho. Não tenho nada na vida: não me formei, nem virei professor, pois fui expulso da faculdade; fui deputado por 26 anos e não tenho patrimônio, não quero mais disputar nada. Sou um militante de ideias! Quero continuar como militante de ideias, então queria agradecer muito por essa oportunidade.

\section{Entrevistadores:}

Nós que agradecemos. Muito obrigado! Obrigada pela disponibilidade!

(Recebido para publicação em setembro de 2020)

(Reapresentado em setembro de 2020)

(Aprovado para publicação em dezembro de 2020)

\section{Cite esta entrevista}

GENOÍNO, José. Entrevista conduzida por Christiane Jalles de Paula e Jorge Chaloub. Revista Estudos Políticos: a publicação semestral do Laboratório de Estudos Hum(e)anos (UFF). Rio de Janeiro, Vol.11 |N.22, pp. 10-34, dezembro de 2020. 